\title{
Impaired DNA Damage Repair Capacity is Associated with an Increased Risk of Esophageal Adenocarcinoma: A Case Control Study
}

\author{
Yonggang $\mathrm{He}^{1,2}$, Jian $\mathrm{Gu}^{1}$, Yilei Gong ${ }^{1}$, Wong-Ho Chow ${ }^{1}$, Jaffer Ajani ${ }^{3}$ and Xifeng $\mathrm{Wu}^{1}{ }^{1, *}$ \\ ${ }^{1}$ Department of Epidemiology, The University of Texas MD Anderson Cancer Center, Houston, Texas, USA \\ ${ }^{2}$ Department of Surgery, Ruijin Hospital, Shanghai Jiao Tong University School of Medicine, Shanghai, China \\ ${ }^{3} \mathrm{GI}$ Medical Oncology, The University of Texas MD Anderson Cancer Center, Houston, Texas, USA \\ *Corresponding author: Xifeng Wu, MD, PhD, Department of Epidemiology, Unit 1340, The University of Texas MD Anderson Cancer Center, 1155 Pressler Blvd, \\ Houston, TX 77030, USA; Tel: 713-745-2485, Fax: 713-745-1165, E-mail: xwu@mdanderson.org.
}

Rec date: Dec 23, 2014, Acc date: Jan 27, 2015, Pub date: Feb 04, 2015

Copyright: (c) $2015 \mathrm{He} \mathrm{Y}$, et al. This is an open-access article distributed under the terms of the Creative Commons Attribution License, which permits unrestricted use, distribution, and reproduction in any medium, provided the original author and source are credited.

\begin{abstract}
Background: Inherited suboptimal DNA repair capacity in peripheral blood lymphocytes (PBLs) can be unmasked by mutagen challenge and has been associated with susceptibility to cancer.

Purpose: To use comet assay to assess the esophageal adenocarcinoma (EAC) risk in relation to mutageninduced DNA damage in PBLs.

Materials and methods: In a case-control study, the baseline, benzo[a]pyrene diol epoxide (BPDE)-induced, and y radiation-induced DNA damage were quantified by the Olive tail moment (TM) in PBLs from 172 Caucasian EAC patients and 154 healthy controls who were frequency matched on age and gender. Logistic regression analysis was used to calculate odds ratios $(\mathrm{OR})$ and $95 \%$ confidence intervals $(\mathrm{Cl})$ to estimate EAC risk in relation to DNA damage.

Results: EAC patients tended to have higher DNA damage than controls, as measured by baseline, net BPDEand net $\mathrm{Y}$ radiation-induced TM, but the difference was statistically significant only for net BPDE-induced DNA damage $(0.88 \pm 0.94$ vs. $0.62 \pm 0.77, P=0.031)$. Using the $75^{\text {th }}$ percentile TM in the controls as cutoff point, we found that high levels of net BPDE- and $y$ radiation-induced DNA damage were associated with significantly increased risks of EAC, with adjusted ORs of $2.15(95 \% \mathrm{Cl}, 1.13-4.10)$ and $2.27(95 \% \mathrm{Cl}, 1.24-4.16)$, respectively. EAC risks were further increased among individuals with both net mutagen-induced DNA damages and exposure to gastroesophageal reflux disease or smoking, known risk factors for EAC.
\end{abstract}

Conclusion: Our results suggest impaired repair capacity of mutagen-induced DNA damage in PBLs assessed by comet assay may be a risk factor of EAC.

Keywords: DNA damage; Comet assay; Esophageal adenocarcinoma; Peripheral blood lymphocytes; Risk

\section{Introduction}

The incidence of esophageal adenocarcinoma (EAC) has increased substantially in the past few decades. In the United States and other Western countries, EAC has become the predominant histological type of esophageal cancer, accounting for at least two-thirds of all esophageal malignancies [1-4]. The principal risk factors for EAC are gastroesophageal reflux disease (GERD), Barrett's esophagus (BE), obesity, and to a lesser extent, smoking [5-8], but the mechanisms through which these risk factors may influence risk remain unclear. Although BE, which develops as a result of chronic GERD, is a premalignant lesion of EAC, the risk of BE progressing to EAC is low ( $<0.5 \%$ per patient year); only a small portion of $\mathrm{BE}$ patients will eventually develop EAC [9-11]. The fact that less than half of EAC patients have symptomatic GERD $[12,13]$ and up to $80 \%$ of EAC patient have no prior diagnosis of $\mathrm{BE}$ even if they have had prior endoscopy [14,15] indicates that additional genetic and/or environmental factors may be involved in the development of EAC.
Identifying genetic risk factors of EAC could provide valuable information for the management of individuals at high risk of this cancer. However, the role of genetic components in the development of EAC is far from to be elucidated. One common genetic characteristic, impaired DNA repair capacity and ensuing genetic instability, has been implicated in many cancers [16-18]. By measuring the DNA damage levels in peripheral blood lymphocytes (PBLs), investigators can reveal individual differences in the ability to repair mutagen challenge-induced DNA damage. The differences in response to DNA damage are phenotypes that reflect an individual's sensitivity to mutagen and repair capacity of DNA damage induced by environmental exposure and therefore have been associated with cancer susceptibility $[19,20]$. Among different assays for measuring DNA damage, the comet assay (also known as single-cell gel electrophoresis) [21] and the later modified alkaline comet assay are simple, objective, relatively high-throughput, and can be used to measure single-strand breaks, double strand breaks, and alkaline-labile sites in a single cell [22]. Over the past decade, comet assay has been used to assess DNA repair capacity in relation to risk of various cancers in numerous population-based studies [23-27]. 
Citation: He Y, Gu J, Gong Y, Chow W, Ajani J, et al (2015) Impaired DNA Damage Repair Capacity is Associated with an Increased Risk of Esophageal Adenocarcinoma: A Case Control Study. J Carcinog Mutagen 6: 215. doi:10.4172/2157-2518.1000215

Page 2 of 7

In a previous pilot study that included mixed histologies and ethnicities, we have shown that the comet assay could be used to assess individual susceptibility to esophageal cancer [23]. In the current study, we included a much larger samples size and restricted the esophageal cancer to the adenocarcinoma subtype among Caucasians only. We evaluated EAC risk in relation to the sensitivity of PBLs to two distinct mutagens, benzo[a]pyrene diol epoxide (BPDE) (a tobacco carcinogen) and $\gamma$ radiation, as indicated by DNA damage measured by comet assay. In addition, we analyzed the joint effects of established risk factors and DNA damage response on EAC risk.

\section{Materials and methods}

\section{Study population}

Caucasian EAC patients and healthy control participants were recruited between October 2003 and March 2009 in an ongoing esophageal cancer study. Patients newly diagnosed with pathologically confirmed EAC, who had not received prior radiotherapy or chemotherapy, were recruited from MD Anderson. There were no restrictions of age, sex, or disease stage for eligibility. Since only about $10 \%$ of the EAC patients recruited were non-Caucasians, we excluded non-Caucasian cases from the study as their numbers were too small for meaningful analysis. Healthy control participants with no history of cancer were recruited from a large pool of volunteers registered with Kelsey-Seybold Clinic, the largest multispecialty physician group in the Houston area. Controls were frequency-matched to cases by age and gender. EAC patients and control participants were interviewed by trained staff at Kelsey-Seybold Clinic locations throughout the Houston area. Interviewers collected data on sociodemographic characteristics, smoking history, alcohol consumption, family history of cancer, occupational history, and medical history (including GERD and $\mathrm{BE}$ status). Ever-smokers were individuals who had smoked at least 100 cigarettes in their lifetimes, including former and current smokers. Never smokers were individuals who had smoked fewer than 100 cigarettes in their lifetimes. Former smokers were defined as those who had quit smoking at least 1 year before diagnosis for EAC patients and before the interview for control participants. At the completion of the in-person interview, $40 \mathrm{ml}$ of blood was drawn into heparinized tubes and delivered to the laboratory for processing. The present study was approved by the institutional review boards at The University of Texas MD Anderson Cancer Center and Kelsey-Seybold Clinic. Written informed consent was obtained from all patients and control participants.

\section{Lymphocyte culture and comet assay}

Lymphocyte culture and comet assay were performed as described previously [24]. Briefly, $0.4 \mathrm{ml}$ of whole blood was cultured in $1.6 \mathrm{ml}$ of RPMI 1640 (JRM Biosciences, Lenexa, Kansas) with15\% fetal calf serum and $1.25 \%$ phytohemagglutinin (Wellcome Research Laboratories, Research Triangle Park, North Carolina) in $60 \mathrm{~mm} \times 15$ $\mathrm{mm}$ Petri dishes at $37{ }^{\circ} \mathrm{C}$ for $96 \mathrm{hr}$. Three cultures for measuring baseline (untreated), BPDE-induced, and $\gamma$ radiation-induced DNA damage were prepared for each study subject. The optimal dose for BPDE was set at $2 \mu \mathrm{M}$ and at treatment duration of $24 \mathrm{hr}$, and the optimal dose of $\gamma$ radiation was set at $1.5 \mathrm{~Gy}$, according to the previous study [27]. After being irradiated, the blood cultures were placed on ice to slow DNA repair, covered with foil to prevent ultraviolet lightinduced DNA damage, and subjected to comet assay within ten minutes.
We used a modified version of the comet assay in alkaline conditions $(\mathrm{pH}>13)$ as originally described by Singh et al [22]. For each sample, two gel settings were made at each end of a slide. PBLs contained in low-melting agarose were placed on a slide that had been pre-coated with a layer of regular agarose. A second layer of lowmelting agarose was then added to fill in any holes in the layer of PBLcontaining agarose. Each layer of agarose had to be hardened before additional agarose layers were added. Detergents and high salt were used to lyse the embedded PBLs. The liberated DNA fragments were subjected to electrophoresis under alkaline conditions at $295-300 \mathrm{~mA}$ for $23 \mathrm{~min}$ and stained with ethidium bromide. Figure 1 shows representative images of cells with no DNA damage (Figure 1A) and severe DNA damage (Figure 1B), respectively.
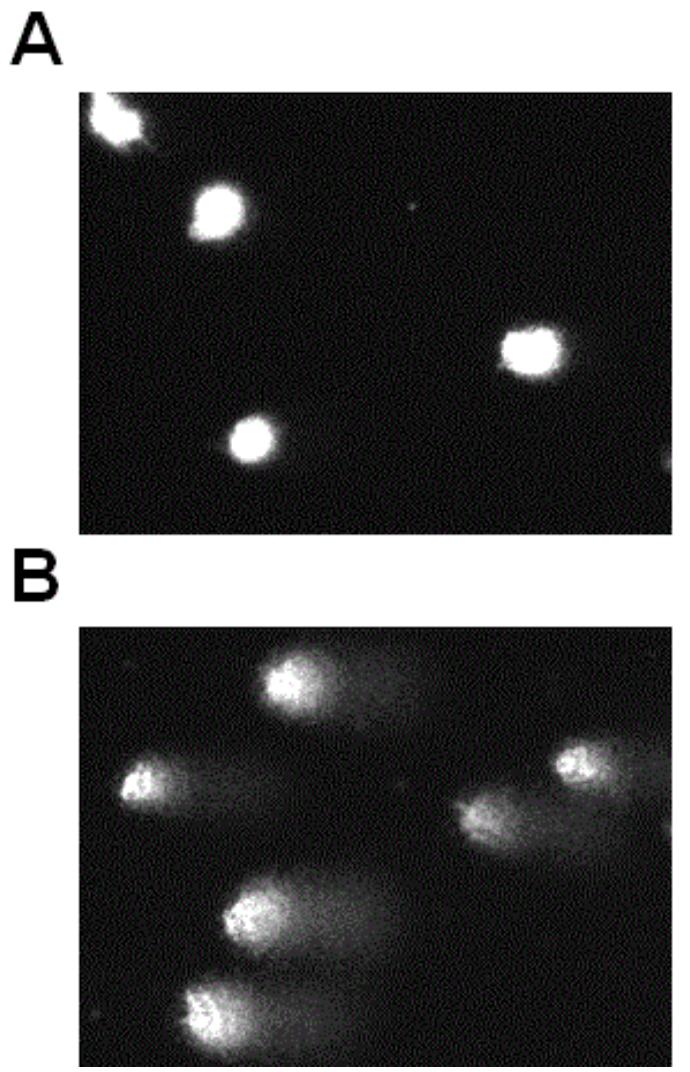

Figure 1: Examples of DNA damage measured by the Comet assay (alkaline electrophoresis of single cells). A) Cells without DNA damage (no tail); B) cells with severe DNA damage (long tails).

The comet assay was performed in reduced illumination to minimize potential DNA damage from ambient ultraviolet radiation. Twenty-five consecutive cells were selected from each end of a slide (50 cells for each sample) under a fluorescent microscope (Nikon, Melville, New York) at 20x magnification and automatically quantified using the Komet 4.0.2 software program (Kinetic Imaging Ltd., Bromborough, U.K.), which determines the Olive tail moment (TM) parameter-(tail mean - head mean) $\times($ tail \% DNA/100)-used to quantify DNA damage [28]. The TM reflects both the length of DNA migration and the percentage of migrated DNA. The mean TMs of the 50 scored cells were calculated for the baseline comets, BPDEinduced comets, and $\gamma$ radiation-induced comets for each study 
Citation: He Y, Gu J, Gong Y, Chow W, Ajani J, et al (2015) Impaired DNA Damage Repair Capacity is Associated with an Increased Risk of Esophageal Adenocarcinoma: A Case Control Study. J Carcinog Mutagen 6: 215. doi:10.4172/2157-2518.1000215

Page 3 of 7

participant. The differences between BPDE- or $\gamma$ radiation-treated TMs and baseline TMs were defined as a pure increase of DNA damage that reflected the net effect of DNA damage and repair after challenge and referred to as "net BPDE-induced TM" and "net $\gamma$ radiation-induced TM." The laboratory technicians were blinded to the case/control status of the samples.

\section{Statistical analysis}

All statistical analyses were performed using the Stata 10.1 statistical software package (Stata Corporation, College Station, Texas). The $\chi^{2}$ test was used to assess differences in categorical data (i.e. sex, smoking status, family history of cancer, family history of esophageal cancer, GERD status, BE status) between the EAC cases and control subjects. The difference in age distributions between the cases and controls was assessed as a continuous variable using the Student $t$-test. The Wilcoxon rank-sum test was used to assess the differences in packyears, baseline TM, net BPDE-induced TM, and net $\gamma$ radiationinduced TM as categorized variables. Odds ratios and $95 \%$ confidence intervals (CIs) were calculated as estimates of EAC relative risk in relation to TMs, which was dichotomized at the 75th percentile based on cutpoints among the controls. Unconditional logistic regression models were used to adjust for potential confounding by age, sex, smoking, GERD, BE status and TM where appropriate. All $\mathrm{P}$ values were two-sided, and associations were considered statistically significant at $\mathrm{P}<0.05$.

\section{Results}

\section{Demographic characteristics in EAC patients and control participants}

The epidemiological data and the differences in DNA damage between the 172 EAC cases and 154 control participants are presented in Table 1. Cases and controls had similar age and gender distributions, as they were frequency-matched on these variables. The average age was 62.2 years for cases and 61.7 years for controls. About $90 \%$ of both cases and controls were men. The proportion of eversmokers among EAC patients (76.2\%) was significantly higher than that among control participants $(52.0 \%$; $\mathrm{P}<0.001)$. Among smokers, the pack-years of cigarettes smoked was also significantly higher among cases than controls $(\mathrm{P}=0.030)$. Moreover, GERD and $\mathrm{BE}$ were significantly more prevalent among cases than controls $(\mathrm{P}<0.001)$. Differences in body mass index (BMI), history of any cancer in firstdegree relatives, and history of esophageal cancer in first-degree relatives between EAC patients and control participants were not statistically significant.

\begin{tabular}{|l|l|l|l|}
\hline Variables & Cases $\mathbf{( N = 1 7 2 )}$ & Controls (N=154) & $\mathbf{P}^{a}$ \\
\hline Age, mean (SD) & $62.2(10.0)$ & $61.7(11.0)$ & 0.660 \\
\hline Sex, N (\%) & $163(94.8)$ & $137(89.0)$ & \\
\hline Male & $9(5.2)$ & $17(11.0)$ & 0.053 \\
\hline Female & $41(23.8)$ & $74(48.0)$ & \\
\hline Smoking status, N (\%) & $92(53.5)$ & $60(39.0)$ & \\
\hline Never & \multicolumn{5}{|l|}{} \\
\hline Former
\end{tabular}

\begin{tabular}{|c|c|c|c|}
\hline Current & 39 (22.7) & $20(13.0)$ & $<0.001$ \\
\hline Never & $41(23.8)$ & $74(48.0)$ & \\
\hline Ever & $131(76.2)$ & $80(52.0)$ & $<0.001$ \\
\hline Pack-years, mean (SD) & $70.2(68.1)$ & $49.4(63.2)$ & 0.030 \\
\hline \multicolumn{4}{|c|}{ Range of pack-years, $\mathrm{N}(\%)$} \\
\hline None & $41(23.8)$ & $74(49.0)$ & \\
\hline$<45$ & $57(33.1)$ & $48(31.8)$ & \\
\hline$\geq 45$ & $74(43.1)$ & $29(19.2)$ & $<0.001$ \\
\hline \multicolumn{4}{|l|}{$\mathrm{BMI}^{\mathrm{b}}, \mathrm{N}(\%)$} \\
\hline$<25$ & $62(39.7)$ & $46(30.3)$ & \\
\hline $25-30$ & 60 (38.5) & $62(40.8)$ & \\
\hline$\geq 30$ & $34(21.8)$ & $44(28.9)$ & 0.163 \\
\hline \multicolumn{4}{|c|}{ Family history of all cancers, $\mathrm{N}(\%)$} \\
\hline No & $23(13.4)$ & $29(18.8)$ & \\
\hline Yes & $149(86.6)$ & $125(81.2)$ & 0.179 \\
\hline \multicolumn{4}{|c|}{ Family history of esophageal cancer, $\mathbf{N}(\%)$} \\
\hline No & $164(95.3)$ & $145(94.2)$ & \\
\hline Yes & $8(4.7)$ & $9(5.8)$ & 0.629 \\
\hline \multicolumn{4}{|l|}{ GERD, N (\%) } \\
\hline No & $61(35.5)$ & $128(83.1)$ & \\
\hline Yes & $111(64.5)$ & $26(16.9)$ & $<0.001$ \\
\hline \multicolumn{4}{|l|}{ BE, N (\%) } \\
\hline No & $103(60.2)$ & $151(98.1)$ & \\
\hline Yes & 68 (39.8) & $3(1.9)$ & $<0.001$ \\
\hline
\end{tabular}

Table 1: Distribution of host characteristics by case-control status . Abbreviations: SD- Standard Deviation; BMI-Body Mass Index; GERD- Gastroesophageal Reflux Disease; BE-Barrett's Esophagus; TM- Tail Moment; BPDE, benzo[a]pyrene diol epoxide. ${ }^{\text {PP values were }}$ derived from $\chi^{2}$ test for categorical data (i.e. sex, ethnicity, smoking status, family history of cancer, family history of esophagus cancer, GERD status, BE status), from the Student t-test for continuous variables (i.e. age ) and from the Wilcoxon rank-sum test for packyears. ${ }^{b} \mathrm{BMI}$ of three years prior to cancer diagnosis for EAC patients and interview for control participants.

\section{Difference in DNA damage levels between cases and controls, and correlations of DNA damage and host characteristics in controls}

EAC patients generally exhibited higher levels of DNA damage than did control participants (Table 2). The net BPDE-induced TM was significantly higher in EAC patients than control participants $(0.88 \pm$ 0.94 vs. $0.62 \pm 0.77 ; \mathrm{P}=0.031)$. However, the differences in baseline TM and net $\gamma$ radiation-induced TM between cases and controls did not attain statistical significance. The correlations of DNA damage 
Citation: He Y, Gu J, Gong Y, Chow W, Ajani J, et al (2015) Impaired DNA Damage Repair Capacity is Associated with an Increased Risk of Esophageal Adenocarcinoma: A Case Control Study. J Carcinog Mutagen 6: 215. doi:10.4172/2157-2518.1000215

Page 4 of 7

variables and host characteristics in control participants were presented in the down part of Table 2. Age, smoking status, and preexisting GERD were not related to baseline or mutagen-induced DNA damage. There was a statistically significant difference of baseline TM between men and women.

\begin{tabular}{|c|c|c|c|c|c|c|}
\hline & \multicolumn{2}{|c|}{ Baseline TM } & \multicolumn{2}{|c|}{$\begin{array}{l}\text { Net BPDE-induced } \\
\text { TM }\end{array}$} & \multicolumn{2}{|c|}{$\begin{array}{l}\text { Net Y radiation } \\
\text { induced TM }\end{array}$} \\
\hline & $\mathbf{N}$ & $\begin{array}{l}\text { Mean } \\
\text { (SD) }\end{array}$ & $\mathbf{N}$ & Mean (SD) & $\mathbf{N}$ & Mean (SD) \\
\hline \multicolumn{7}{|l|}{ Overall } \\
\hline Cases & 172 & $\begin{array}{l}1.78 \\
(1.01)\end{array}$ & 143 & $0.88(0.94)$ & 167 & $1.80(1.47)$ \\
\hline Controls & 154 & $\begin{array}{l}1.60 \\
(1.03)\end{array}$ & 120 & $0.62(0.77)$ & 146 & $1.60(1.25)$ \\
\hline $\mathrm{P}^{a}$ & & 0.051 & & 0.031 & & 0.318 \\
\hline \multicolumn{7}{|c|}{ Characteristics in controls } \\
\hline \multicolumn{7}{|l|}{ Sex } \\
\hline Male & 137 & $\begin{array}{l}1.54 \\
(1.01)\end{array}$ & 106 & $0.57(0.69)$ & 130 & $1.60(1.30)$ \\
\hline Female & 17 & $\begin{array}{l}2.10 \\
(1.09)\end{array}$ & 14 & $1.02(1.18)$ & 16 & $1.62(0.88)$ \\
\hline $\mathrm{Pa}$ & & 0.010 & & 0.233 & & 0.483 \\
\hline \multicolumn{7}{|l|}{ Age } \\
\hline$<62$ & 71 & $\begin{array}{l}1.53 \\
(0.94)\end{array}$ & 53 & $0.50(0.70)$ & 67 & $1.62(1.30)$ \\
\hline$\geq 62$ & 83 & $\begin{array}{l}1.66 \\
(1.11)\end{array}$ & 67 & $0.72(0.81)$ & 79 & $1.58(1.22)$ \\
\hline $\mathrm{Pa}^{\mathrm{a}}$ & & 0.551 & & 0.247 & & 0.874 \\
\hline \multicolumn{7}{|c|}{ Smoking status } \\
\hline Never & 74 & $\begin{array}{l}1.49 \\
(0.93)\end{array}$ & 55 & $0.52(0.74)$ & 68 & $1.57(1.21)$ \\
\hline Ever & 80 & $\begin{array}{l}1.71 \\
(1.11)\end{array}$ & 65 & $0.71(0.79)$ & 78 & $1.63(1.30)$ \\
\hline $\mathrm{Pa}^{a}$ & & 0.280 & & 0.117 & & 0.627 \\
\hline \multicolumn{7}{|l|}{ GERD } \\
\hline No & 128 & $\begin{array}{l}1.64 \\
(1.09)\end{array}$ & 100 & $0.59(0.70)$ & 122 & $1.58(1.24)$ \\
\hline Yes & 26 & $\begin{array}{l}1.40 \\
(0.69)\end{array}$ & 20 & $0.77(1.04)$ & 24 & $1.73(1.36)$ \\
\hline $\mathrm{P}^{\mathrm{a}}$ & & 0.537 & & 0.379 & & 0.675 \\
\hline
\end{tabular}

Table 2: DNA damage in overall cases and controls, and correlations of DNA damage and selected host characteristics in control participants. ${ }^{a}$ Wilcoxon rank-sum test was used to evaluate the difference in DNA damages among subgroups. Note: some blood samples were not assayed for mutagen-induced DNA damage.

\section{EAC risk in relation to DNA damage}

Individuals with high DNA damage levels as measured by three TM indicators (baseline, BPDE-induced, and $\gamma$ radiation-induced) were at an elevated risk of developing EAC (Table 3). Compared to individuals with below $75^{\text {th }}$ percentile of DNA damage, the EAC risk (adjusted for age, sex, smoking, GERD, and BE status) were significantly elevated for those with higher than $75^{\text {th }}$ percentile of net BPDE-induced TM $(\mathrm{OR}=2.15 ; 95 \% \mathrm{CI}=1.13-4.10 ; \mathrm{P}=0.020)$ or net $\gamma$ radiation-induced $\mathrm{TM}(\mathrm{OR}=2.27 ; 95 \% \mathrm{CI}=1.24-4.16 ; \mathrm{P}=0.008)$. The risk associated with baseline $\mathrm{TM}$ was also increased $(\mathrm{OR}=1.66 ; 95 \% \mathrm{CI}=0.91-3.05$; $\mathrm{P}=0.100$ ), but did not reach statistical significance. In addition, there was a significant joint effect between BPDE-induced and $\gamma$ radiationinduced mutagen sensitivities associated with EAC risk. Compared to individuals with low sensitivity to both mutagens, those with high sensitivity to either one of the two mutagens had a 1.6-fold higher risk $(\mathrm{OR}=1.60 ; 95 \% \mathrm{CI}=0.80-3.20)$ and those with high sensitivity to both mutagens had a more than 4 -fold higher risk of EAC (OR 4.02; 95\% $\mathrm{CI}=1.64-9.86)(\mathrm{P}$ for trend $=0.002)$.

\begin{tabular}{|c|c|c|c|c|}
\hline $\begin{array}{l}\text { DNA damage } \\
\text { variables }\end{array}$ & Cases & Controls & $\begin{array}{l}\text { Adjusted } \quad \text { OR }(95 \% \\
\mathrm{Cl})^{\mathrm{a}}\end{array}$ & $\mathrm{P}^{\mathrm{b}}$ \\
\hline \multicolumn{5}{|l|}{ Baseline TM } \\
\hline \multicolumn{5}{|l|}{$\begin{array}{l}\text { By } 75^{\text {th }} \text { percentile } \\
\text { value, } N(\%)\end{array}$} \\
\hline Low $^{c}$ & $117(68.0)$ & $116(75.3)$ & 1.00 (ref.) & \\
\hline $\mathrm{High}^{\mathrm{d}}$ & $55(32.0)$ & $38(24.7)$ & $1.66(0.91-3.05)$ & 0.100 \\
\hline \multicolumn{5}{|l|}{ Net BPDE-induced TM } \\
\hline \multicolumn{5}{|l|}{$\begin{array}{l}\text { By } 75^{\text {th }} \text { percentile } \\
\text { value, } N(\%)\end{array}$} \\
\hline Low $^{c}$ & $90(62.9)$ & $90(75.0)$ & 1.00 (ref.) & \\
\hline $\mathrm{High}^{\mathrm{d}}$ & $53(37.1)$ & $30(25.0)$ & $2.15(1.13-4.10)$ & 0.020 \\
\hline \multicolumn{5}{|c|}{ Net $y$ radiation-induced TM } \\
\hline \multicolumn{5}{|l|}{$\begin{array}{l}\text { By } 75^{\text {th }} \text { percentile } \\
\text { value, } \mathrm{N}(\%)\end{array}$} \\
\hline Low $^{\mathrm{C}}$ & $109(65.3)$ & $110(75.3)$ & 1.00 (ref.) & \\
\hline $\mathrm{High}^{\mathrm{d}}$ & $58(43.1)$ & $36(24.7)$ & $2.27(1.24-4.16)$ & 0.008 \\
\hline \multicolumn{5}{|c|}{ Both net BPDE-induced and net $y$ radiation-induced TM } \\
\hline Low & $66(46.8)$ & $66(55.9)$ & 1.00 (ref.) & \\
\hline Intermediate $\mathrm{e}^{\mathrm{e}}$ & $41(29.1)$ & $40(33.9)$ & $1.60(0.80-3.20)$ & 0.182 \\
\hline High & $34(24.1)$ & $12(10.2)$ & $4.02(1.64-9.86)$ & 0.002 \\
\hline \multicolumn{4}{|l|}{$P$ for trend } & 0.002 \\
\hline
\end{tabular}

Table 3: Risk Estimates of EAC for baseline, net BPDE-induced and net $\gamma$ radiation induced DNA Damage. ${ }^{a}$ Adjusted by sex, age, smoking status, GERD and BE status, family history of all cancer. ${ }^{b} \mathrm{P}$ values were derived from the Wilcoxon rank-sum test for baseline TM, net BPDE-induced TM, and net $\gamma$ radiation-induced TM. " "Low" referred to subjects with $\mathrm{TM}<75 \%$ cut-off of the controls. "High" referred to subjects with $\mathrm{TM} \geq 75 \%$ cut-off of the controls. e Participants were classified as having induced DNA damage value either $\geq 75 \%$ for net $\gamma$ 
Citation: He Y, Gu J, Gong Y, Chow W, Ajani J, et al (2015) Impaired DNA Damage Repair Capacity is Associated with an Increased Risk of Esophageal Adenocarcinoma: A Case Control Study. J Carcinog Mutagen 6: 215. doi:10.4172/2157-2518.1000215

Page 5 of 7

radiation-induce $\mathrm{TM}$ and $<75 \%$ for net BPDE-induced $\mathrm{TM}$ or $\geq 75 \%$ for net BPDE-induced TM and $<75 \%$ for net $\gamma$ radiation-induced TM.

\section{Joint effects of DNA damage and other risk factors of EAC}

Smokers and individuals with GERD who had high levels of mutagen-induced DNA damage were at a particularly elevated risk for EAC (Table 4). Compared to individuals with low BDPE-induced DNA damage levels and negative for GERD, risk increased to 2.05 (95\% CI $0.94-4.47)$ for those with high DNA damage level and no GERD, 4.83 (95\% CI 2.14 - 10.87) for those with low DNA damage level but positive for GERD, and 11.54 (95\% CI 3.84 - 34.93) for those with both high DNA damage level and GERD. The joint effect, however, did not reach statistical significance, which indicated that these factors might have independently effect on the risk of EAC. A similar pattern of consistently increasing risks of EAC was also observed with joint effects of net BPDE-induced DNA damage level and smoking, and with joints effects of net $\gamma$ radiation-induced DNA damage level and GERD or smoking. Compared to individuals with neither risk factors, the risk was 7.26 (95\% CI 2.80-18.84) for smokers with high net BPDE-induced DNA damage level, 9.85 (95\% CI 3.50-27.71) for those exposed to GERD and high net $\gamma$ radiationinduced DNA damage level, and 6.93 (95\% CI 2.92-16.45) for smokers with high net $\gamma$ radiation-induced DNA damage level.

\begin{tabular}{|c|c|c|c|c|}
\hline Risk factors & $\begin{array}{l}\text { Cases, } \mathrm{N} \\
(\%)\end{array}$ & $\begin{array}{l}\text { Controls, } \quad \mathrm{N} \\
(\%)\end{array}$ & $\begin{array}{l}\text { Adjusted OR }(95 \% \\
\mathrm{CI})^{\mathrm{a}}\end{array}$ & $\mathbf{P}$ \\
\hline \multicolumn{5}{|c|}{ Net BPDE-induced \& GERD } \\
\hline Low \& GERD(-) & $29(20.3)$ & $76(63.3)$ & 1.00 (ref.) & \\
\hline High \& GERD(-) & $23(16.1)$ & $24(20.0)$ & $2.05(0.94-4.47)$ & 0.070 \\
\hline Low \& GERD $(+)$ & $61(42.7)$ & $14(11.7)$ & $4.83(2.14-10.87)$ & $<0.001$ \\
\hline High \& GERD $(+)$ & $30(20.9)$ & $6(5.0)$ & $11.54(3.84-34.93)$ & $<0.001$ \\
\hline \multicolumn{4}{|l|}{$P$ for interaction } & 0.835 \\
\hline \multicolumn{5}{|c|}{ Net BPDE-induced \& smoking status } \\
\hline $\begin{array}{l}\text { Low \& never } \\
\text { smoking }\end{array}$ & $19(13.3)$ & $44(36.7)$ & 1.00 (ref.) & \\
\hline $\begin{array}{l}\text { High \& never } \\
\text { smoking }\end{array}$ & $15(10.5)$ & $11(9.2)$ & $2.96(0.88-10.00)$ & 0.081 \\
\hline $\begin{array}{l}\text { Low \& ever } \\
\text { smoking }\end{array}$ & $71(49.7)$ & $46(38.3)$ & $3.83(1.61-9.11)$ & $<0.001$ \\
\hline $\begin{array}{l}\text { High \& ever } \\
\text { smoking }\end{array}$ & $38(26.5)$ & $19(15.8)$ & $7.26(2.80-18.84)$ & $<0.001$ \\
\hline \multicolumn{4}{|l|}{$P$ for interaction } & 0.548 \\
\hline \multicolumn{5}{|c|}{ Net y radiation-induced \& GERD } \\
\hline Low \& GERD(-) & $34(20.4)$ & $92(63.0)$ & 1.00 (ref.) & \\
\hline High \& GERD(-) & $27(16.2)$ & $30(20.5)$ & $2.64(1.30-5.37)$ & 0.007 \\
\hline Low \& GERD $(+)$ & $75(44.9)$ & $18(12.3)$ & $6.42(3.09-13.37)$ & $<0.001$ \\
\hline High \& GERD $(+)$ & $31(18.5)$ & $6(4.1)$ & $9.85(3.50-27.71)$ & $<0.001$ \\
\hline$P$ for interaction & & & & 0.420 \\
\hline \multicolumn{5}{|c|}{ Net $y$ radiation-induced \& smoking status } \\
\hline
\end{tabular}

\begin{tabular}{|l|l|l|l|l|}
\hline $\begin{array}{l}\text { Low \& never } \\
\text { smoking }\end{array}$ & $32(19.2)$ & $50(34.2)$ & 1.00 (ref.) & \\
\hline $\begin{array}{l}\text { High \& never } \\
\text { smoking }\end{array}$ & $7(4.2)$ & $18(12.3)$ & $1.14(0.36-3.58)$ & 0.823 \\
\hline $\begin{array}{l}\text { Low \& ever } \\
\text { smoking }\end{array}$ & $77(46.1)$ & $60(41.2)$ & $2.25(1.08-4.70)$ & 0.030 \\
\hline $\begin{array}{l}\text { High \& ever } \\
\text { smoking }\end{array}$ & $51(30.5)$ & $18(12.3)$ & $6.93(2.92-16.45)$ & $<0.001$ \\
\hline P for interaction & & & 0.152 \\
\hline
\end{tabular}

Table 4: Joint effects of DNA damage, GERD status, and smoking status. ${ }^{\text {a }}$ Adjusted by sex, age, BE, family history of all cancer.

\section{Discussion}

In the present study, we found that mutagen-induced DNA damage response in PBLs is associated with an increased risk of EAC. In addition, we demonstrated that DNA damage markers and established epidemiologic risk factors jointly further increased EAC risk.

Inter-individual variation in the metabolism of environmental exposures is thought to be associated with the variability of cancer susceptibility among humans. To date, very little is known about the genetic factors that confer EAC susceptibility [29]. Genetic variations in the detoxification enzyme genes (e.g., GSTP1, GSTM1, and GSTT1) and DNA repair genes have been investigated as susceptibility factors for EAC, but the results have been inconsistent [30-34]. DNA damage response has merged an intermediate phenotype that confers cancer susceptibility. Our findings suggest that a person's inherent deficiency in DNA repair capacity towards mutagen challenge is a predisposing factor for EAC.

We mainly used net mutagen-induced DNA damage levels to assess EAC risk, although there were also significant differences in induced damage levels after the treatment of BPDE and $\gamma$ radiation between cases and control (data not shown). As a result of subtracting the baseline level from induced levels, the net BPDE and $\gamma$ radiation induced DNA damage levels represent the net change of DNA damage after mutagen challenge, therefore better reflect individual sensitivity to mutagen and capacity of DNA damage repair. Using this variable can minimize the potential confounding effect of baseline DNA damage level on that measured after mutagen treatments. Previous studies using comet assays showed that constitutive DNA damage (the baseline TM measured) was significantly associated with an increased risk of esophageal cancer [23], bladder cancer [24], kidney cancer [25], and lung cancer [35]. In the present study, we found only borderline significance in the difference in baseline DNA damage between EAC patients and control participants, which may be partly explained by the weaker association with the baseline TM and our relatively small study size. The significance of the capacity of limiting endogenous DNA damage on the cancer susceptibility may require further confirmation in larger scale studies. In contrast, the significant and similar risk estimates for net BPDE-induced and net $\gamma$ radiationinduced DNA damage levels reflected the stronger associations between them and EAC risk, indicating the capacity of repairing mutagen induced DNA damage might serve better in assessing EAC risk.

In this study, we used the comet assay to assess DNA damage induced by BPED and $\gamma$ radiation to reflect distinct pathways of host 
Page 6 of 7

DNA repair capacity. We found that multiple deficiencies in DNA repair have a cumulative effect in the development of EAC. BPDE induces bulky DNA adducts that are repaired by the nucleotide excision repair pathway, whereas $\gamma$ radiation induces single- and double-strand breaks that are repaired by base excision repair and the double-strand break repair pathway, respectively. Our results demonstrated that the EAC risk of individuals who were sensitive to both mutagens was significantly higher than that of individuals who were sensitive to only one mutagen. In addition, assessing the multiplicative joint effects of DNA damage response with preexisting GERD or smoking status significantly enhanced the power of predicting EAC risk, which is consistent with previous findings for other cancers [36,37]. Considering the joint effects of DNA response phenotypes and environmental risk factors will help to identify individuals at particularly high risk of EAC. Therefore, individuals with multiple risk factors of EAC may need to be enrolled in an enhanced screening strategy to achieve an early detection of the disease.

Potential limitations of our study should be considered. First, the status of preexisting GERD and BE were self-reported. Given that BE may occur in the absence of symptoms of chronic reflux [38], participants who reported they did not have BE due to lack of symptoms may in fact had the disease. Nevertheless, the proportion of control participants who reported having BE was $1.7 \%$ (3/177), which is comparable with the prevalence of BE identified through endoscopy reported in a large population-based study in a western country [39]. Second, our study did not collect data on usual BMI and was therefore not able to assess its association with EAC risk. We found no association with BMI around the time of EAC diagnosis, which could have been influenced by the cancer status. However, our data confirmed that GERD, which is considered a pathway through which BMI may increase EAC risk, occurred more frequently in EAC patients than in controls. Another potential limitation was that, due to the very low occurrence of $\mathrm{BE}$ in control participants, we could not compare the DNA damage levels of control participants with and without preexisting BE. Our study included only Caucasian participants, therefore its results may not be generalizable to other racial/ethnic populations. Finally, because we used post-diagnostic blood samples from patients, reverse causation is a potential concern. We tried to limit this concern by using samples from newly diagnosed, previously untreated patients. A previous study found no difference in comet assay results before and after cancer diagnosis [40], although it should be mentioned that in the study the sample size was small and the comet assay was performed in lymphoblastoid cell lines. It has been shown in a prospective study that high sensitivity to bleomycin in PBLs of BE patients, particularly those with $17 \mathrm{p}$ loss of heterozygosity, is associated with an increased risk of progression to EAC. This study suggests that inherent deficiency of DNA repair capacity already exists in the precursor of EAC and could serve as a biomarker for predicting the development of EAC [41].

In conclusion, identifying genetic factors that confer EAC susceptibility will help to target individuals with high risk of the disease. Our study demonstrates that mutagen-induced DNA damage in PBLs as measured by comet assay reflected inherent deficiency of DNA repair capacity in response to DNA damage challenging and is associated with an increased risk of developing EAC. Further studies to comprehensively reveal the genetic predisposition to EAC are warranted.

\section{Acknowledgments}

This study was supported in part by National Cancer Institute grant (R01 CA111922). Additional funding was provided by the Premalignant Genome Atlas program of the Duncan Family Institute for Cancer Prevention and Risk Assessment and institutional support for the Center for Translational and Public Health Genomics at The University of Texas MD Anderson Cancer Center.

\section{Disclosure Statement}

The authors have no conflict of interest.

\section{References}

1. Bollschweiler E, Wolfgarten E, Gutschow C, Hölscher AH (2001) Demographic variations in the rising incidence of esophageal adenocarcinoma in white males. Cancer 92: 549-555.

2. Brown LM, Devesa SS, Chow WH (2008) Incidence of adenocarcinoma of the esophagus among white Americans by sex, stage, and age. J Natl Cancer Inst 100: 1184-1187.

3. Thrift AP, Whiteman DC (2012) The incidence of esophageal adenocarcinoma continues to rise: analysis of period and birth cohort effects on recent trends. Annals of oncology 12: 3155-3162.

4. Trivers KF ,Sabatino SA, Stewart SL (2008) Trends in esophageal cancer incidence by histology, United States, 1998-2003. Int J Cancer 123: 1422-1428.

5. Chow WH, Finkle WD, McLaughlin JK, Frankl H, Ziel HK, et al. (1995) The relation of gastroesophageal reflux disease and its treatment to adenocarcinomas of the esophagus and gastric cardia. JAMA 274: 474-477.

6. Engel LS, Chow WH, Vaughan TL, Gammon MD, Risch HA, et al. (2003) Population attributable risks of esophageal and gastric cancers. J Natl Cancer Inst 95: 1404-1413.

7. Olsen CM, Pandeya N, Green AC, Webb PM, Whiteman DC; Australian Cancer Study (2011) Population attributable fractions of adenocarcinoma of the esophagus and gastroesophageal junction. Am J Epidemiol 174: 582-590.

8. Merry AH, Schouten LJ, Goldbohm RA, van den Brandt PA (2007) Body mass index, height and risk of adenocarcinoma of the oesophagus and gastric cardia: a prospective cohort study. Gut 56: 1503-1511.

9. de Jonge PJ, van Blankenstein M, Looman CW, Casparie MK, Meijer GA, et al. (2010) Risk of malignant progression in patients with Barrett's oesophagus: a Dutch nationwide cohort study. Gut 59: 1030-1036.

10. Milind R ,Attwood SE (2012) Natural history of Barrett's esophagus. World J Gastroenterol 18: 3483-3491.

11. Desai TK ,Krishnan K, Samala N, Singh J, Cluley J, et al. (2012) The incidence of oesophageal adenocarcinoma in non-dysplastic Barrett's oesophagus: a meta-analysis. Gut 61: 970-976.

12. Bytzer P, Christensen PB, Damkier P, Vinding K, Seersholm N (1999) Adenocarcinoma of the esophagus and Barrett's esophagus: a populationbased study. Am J Gastroenterol 94: 86-91.

13. Corley DA, Levin TR, Habel LA, Weiss NS, Buffler PA (2002) Surveillance and survival in Barrett's adenocarcinomas: a populationbased study. Gastroenterology 122: 633-640.

14. Farrow DC,Vaughan TL, Sweeney C, Gammon MD, Chow WH, et al. (2000) Gastroesophageal reflux disease, use of H2 receptor antagonists, and risk of esophageal and gastric cancer. Cancer Causes Control 11: 231-238.

15. Lagergren J ,Bergström R, Lindgren A, Nyrén O (1999) Symptomatic gastroesophageal reflux as a risk factor for esophageal adenocarcinoma. N Engl J Med 340: 825-831.

16. Berwick M, Vineis $P$ (2000) Markers of DNA repair and susceptibility to cancer in humans: an epidemiologic review. Journal of the National Cancer Institute 92:874-897 
Citation: He Y, Gu J, Gong Y, Chow W, Ajani J, et al (2015) Impaired DNA Damage Repair Capacity is Associated with an Increased Risk of Esophageal Adenocarcinoma: A Case Control Study. J Carcinog Mutagen 6: 215. doi:10.4172/2157-2518.1000215

Page 7 of 7

17. Decordier I, Loock KV, Kirsch-Volders M (2010) Phenotyping for DNA repair capacity. Mutat Res 705: 107-129.

18. Hoeijmakers JH1 (2001) Genome maintenance mechanisms for preventing cancer. Nature 411: 366-374.

19. Hsu TC Spitz MR, Schantz SP (1991) Mutagen sensitivity: a biological marker of cancer susceptibility. Cancer Epidemiol Biomarkers Prev 1: 83-89.

20. Wu X Gu J, Spitz MR (2007) Mutagen sensitivity: a genetic predisposition factor for cancer. Cancer Res 67: 3493-3495.

21. Ostling O, Johanson KJ (1984) Microelectrophoretic study of radiationinduced DNA damages in individual mammalian cells. Biochem Biophys Res Commun 123: 291-298.

22. Singh NP, McCoy MT, Tice RR (1988) A simple technique for quantitation of low levels of DNA damage in individual cells. Experimental cell research 175:184-189

23. Shao L, Lin J, Huang M, Ajani JA, Wu X (2005) Predictors of esophageal cancer risk: assessment of susceptibility to DNA damage using comet assay. Genes Chromosomes Cancer 44: 415-422.

24. Schabath MB Spitz MR, Grossman HB, Zhang K, Dinney CP, et al. (2003) Genetic instability in bladder cancer assessed by the comet assay. J Natl Cancer Inst 95: 540-547.

25. Lin X, Wood CG, Shao L, Huang M, Yang H, et al. (2007) Risk assessment of renal cell carcinoma using alkaline comet assay. Cancer 110: $282-288$

26. Jaoszyaski P, Kujawski M, Czub-Swierczek M, Markowska J, Szyfter K (1997) Bleomycin-induced DNA damage and its removal in lymphocytes of breast cancer patients studied by comet assay. Mutat Res 385: 223-233.

27. Zhang H Buchholz TA, Hancock D, Spitz MR, Wu X (2000) Gammaradiation-induced single cell DNA damage as a measure of susceptibility to lung cancer: a preliminary report. Int J Oncol 17: 399-404.

28. Olive PL, Banath JP, Durand RE (1990) Heterogeneity in radiationinduced DNA damage and repair in tumor and normal cells measured using the "comet" assay. Radiation research 122:86-94

29. Lao-Sirieix P Caldas C, Fitzgerald RC (2010) Genetic predisposition to gastro-oesophageal cancer. Curr Opin Genet Dev 20: 210-217.

30. Kala Z, Dolina J, Marek F, Izakovicova Holla L (2007) Polymorphisms of glutathione S-transferase M T1 and P1 in patients with reflux esophagitis and Barrett's esophagus. J Hum Genet 52: 527-534.
31. Murphy SJ ,Hughes AE, Patterson CC, Anderson LA, Watson RG, et al. (2007) A population-based association study of SNPs of GSTP MnSOD, GPX2 and Barrett's esophagus and esophageal adenocarcinoma. Carcinogenesis 28: 1323-1328.

32. Bani-Hani K, Martin IG, Hardie LJ, Mapstone N, Briggs JA, et al. (2000) Prospective study of cyclin D1 overexpression in Barrett's esophagus: association with increased risk of adenocarcinoma. J Natl Cancer Inst 92: 1316-1321.

33. Murray L ,Sedo A, Scott M, McManus D, Sloan JM, et al. (2006) TP53 and progression from Barrett's metaplasia to oesophageal adenocarcinoma in a UK population cohort. Gut 55: 1390-1397.

34. Izzo JG, Wu TT, Wu X, Ensor J, Luthra R, et al (2007) Cyclin D1 guanine/adenine 870 polymorphism with altered protein expression is associated with genomic instability and aggressive clinical biology of esophageal adenocarcinoma. J Clin Oncol 25: 698-707

35. Orlow I, Park BJ, Mujumdar U, Patel H, Siu-Lau P, et al. (2008) DNA damage and repair capacity in patients with lung cancer: prediction of multiple primary tumors. J Clin Oncol 26: 3560-3566.

36. Cloos J, Spitz MR, Schantz SP, Hsu TC, Zhang ZF, et al. (1996) Genetic susceptibility to head and neck squamous cell carcinoma. J Natl Cancer Inst 88: 530-535.

37. Wu X , Yu H, Amos CI, Hong WK, Spitz MR (2000) Joint effect of insulin-like growth factors and mutagen sensitivity in lung cancer risk. J Natl Cancer Inst 92: 737-743.

38. Rex DK, Cummings OW, Shaw M, Cumings MD, Wong RK, et al. (2003) Screening for Barrett's esophagus in colonoscopy patients with and without heartburn. Gastroenterology 125: 1670-1677.

39. Ronkainen J ,Aro P, Storskrubb T, Johansson SE, Lind T, et al. (2005) Prevalence of Barrett's esophagus in the general population: an endoscopic study. Gastroenterology 129: 1825-1831.

40. Bhatti P, Sigurdson AJ, Thomas CB, Iwan A, Alexander BH, et al (2008) No evidence for differences in DNA damage assessed before and after a cancer diagnosis. Cancer Epidemiol Biomarkers Prev17: 990-994

41. Chao DL, Maley CC, Wu X, Farrow DC, Galipeau PC, et al. (2006) Mutagen sensitivity and neoplastic progression in patients with Barrett's esophagus: a prospective analysis. Cancer Epidemiol Biomarkers Prev 15: 1935-1940. 